\title{
The impact of motherhood on sexuality
}

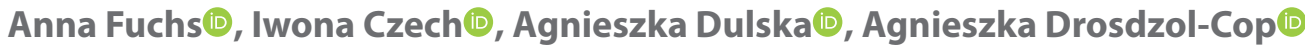 \\ Chair and Department of Gynecology, Obstetrics and Oncological Gynecology, School of Health Science in Katowice, \\ Medical University of Silesia, Poland
}

\begin{abstract}
Objectives: Motherhood is a beautiful, extremely satisfying time ina woman's life, but also very challenging at the same time. Forty weeks of pregnancy, delivery, postpartum and breastfeeding periods affect physiological and mental functions that may unfortunately hinder women sexuality.

Material and methods: A longitudinal study was carried out. The questionnaire was developed to include a validated tool as wells as socio-demographic and medical data. The completely self-administered questionnaire was provided to patients twice - before pregnancy and postpartum. Finally, 398 women were included in the study and filled out the survey.

Results: Pregnancy and childbirth significantly $(p<0.001)$ reduce female sexual activity by lowering FSFI score. A similar relationship occurs in the six domains included in the FSFI scale.The number of women who received $\leq 26$ points (which may indicate sexual dysfunctions) before pregnancy is 34 (8.54\%) and after giving birth it is 167 (41.96\%)

Conclusions: Pregnancy and childbirth significantly reduce female sexual activity by lowering FSFI score. The number of women who with sexual dysfunctions increases fivefold after giving birth, and may even reach the value of $40 \%$ of young mothers. The role of the medical personnel in maintain women's sexual health is extremely important.
\end{abstract}

Key words: sexuality; pregnancy; intercourse; desire; motherhood; pain; sexual dysfunction

Ginekologia Polska 2021; 92, 1: 1-6

\section{INTRODUCTION}

Motherhood is a beautiful, extremely satisfying time in a woman's life, but also very challenging at the same time. Forty weeks of pregnancy, delivery, postpartum and breastfeeding periods affect physiological and mental functions that may unfortunately hinder a woman's sexuality.

After childbirth interest in sex and sexual activity decreases. This phenomenon may be caused by vaginal injuries, as well as episiotomy and discomfort provoked by them. Women in puerperium also complain of urinary incontinence, painful relationships due to insufficient arousal after childbirth and organ mismatch feeling.

Sexuality is a complex process, coordinated by the nervous, vascular and endocrine systems. Individually, sexuality incorporates family, societal and religious beliefs, as well as being altered with aging, health status and personal experience [1].

Sexuality is closely related to the concept of sexual health. Until the twentieth century, sexual health was identified with parenthood and vaginal intercourse. In China, sexual health was also correlated with the state of mind and the harmony of nature. In Europe, however, sexuality was a taboo subject, and attempts to talk about it were considered completely unfit, sometimes even referred to as pathology. It was not until 1944 that a new definition of sexual health was published at the United Nations International Conference for Population and Development [2, 3].

According to the current working definition given by the World Health Organization (WHO), sexual health is a state of physical, emotional, mental and social well-being in relation to sexuality; it is not merely the absence of disease, dysfunction or infirmity. Sexual health requires a positive and respectful approach to sexuality and sexual relationships, as well as the possibility of having pleasurable and safe sexual experiences, free of coercion, discrimination and violence. For sexual health to be attained and maintained, the sexual rights of all persons must be respected, protected and fulfilled [4].

The prevalence of sexual dysfunction increases as women age. About $40-45 \%$ of adult women have at least one manifest sexual dysfunction. Unfortunately, this number significantly elevates when talking about postpartum period [5].

Sexual intercourse of women in the early period of motherhood is poorly understood, because there is little research in this area. The results of scientific research that have been known so far confirm the fact that women during the postnatal period need sexual contact, but their 
frequency and character vary depending on the course of labor, procedures performed during childbirth, its complications, breastfeeding and of course closeness of the relationship with the partner during this period [6].

\section{Aim}

This study investigates the quality of sexual life of women in the first year after delivery compared to the time before pregnancy. Our research also focuses on the self-assessment of women after childbirth and the frequency of side effects of labour such as pain during intercourse, impaired vaginal lubrication and problems in reaching orgasm. A better understanding of the topic of postpartum female sexual disfunction and related factors can also be the basis for improving education and care for women during this period.

\section{MATERIAL AND METHODS}

\section{Study group}

A longitudinal study was carried out at the Department of Pregnancy Pathology, Department of Woman's Health, School of Health Sciences in Katowice of Medical University of Silesia in Poland, between May 2017 and June 2019. Silesia, located in south-western Poland, is one of the biggest Polish urban areas with a population of 4548180 people. Approximately 45000 children are born there each year.

The questionnaire was developed to include a validated tool as wells as socio-demographic and medical data. To measure of sexual functioning in women, a standardized Female Sexual Function Index (FSFI) questionnaire was used. The completely self-administered questionnaire was provided to patients two times. Initially, the survey was completed by women thinking of pregnancy in future months ( $n=500)$ at random while waiting for their routine medical check-ups. The second time, the patients were interviewed at six months postpartum. At this time, the survey was completed by 418 women. Exclusion criteria were incorrectly completed questionnaire and missing data $(n=6)$ and lack of sexual activity after childbirth $(n=14)$. Finally, 398 women were included in the study and filled out the survey.

\section{Questionnaire}

The survey was divided into four parts. The first part included questions about socio-demographic characteristics, obstetric history, possible complications and perinatal injuries in previous pregnancies and self-esteem before pregnancy.

In the second part of the questionnaire patients could find the Polish version of the FSFI questionnaire. FSFI is a validated questionnaire containing 19 questions and it measures women's sexual functioning across six domains: desire (questions 1 and 2; score range 1-5), arousal (questions $3,4,5$, 6; score range $0-5$ ), lubrication (questions 7,8 , 9,10 ; score range $0-5$ ), orgasm (questions $11,12,13$; score range $0-5$ ), satisfaction (questions $14,15,16$; score range $1-5$ ) and pain (questions 17, 18, 19; score range $0-5$ ) during last 4 weeks. The full- scale score range is $2-36$ and lower scores are associated with worse sexual function [7].

The third and the fourth part of the questionnaire were completed by the patients at six months postpartum.

In the third part of survey the same FSFI questionnaire was presented, while in the fourth part of the questionnaire patients were asked about the sexual initiation after delivery, patient's self-esteem, the feel of attractiveness, breastfeeding and its influence on relationship with the partner.

\section{Statistical analysis}

The statistical analysis was carried out based on the procedures available in the licensed software Statistica version 13. Quantitative variables are presented in the form of arithmetic mean and standard deviation (SD) or median and interquartile range (IQR). The qualitative variables are presented in the form of absolute value and/or interest. Intergroup differences for quantitative variables were tested using parametric (Student's or ANOVA) or non-parametric tests (U Mann-Whitney or Kruskal-Wallis), previously verifying the nature of their distribution by the Shapiro-Wilk or Smirnov-Kolmogorov test. In the case of qualitative variables, the chi-square test or Fisher's exact test was used. The criterion of statistical significance was $p<0.05$.

\section{RESULTS \\ Group characteristics}

The median age of the studied group was $28(\mathrm{IQR}=25-31)$. Among the 398 patients surveyed, 242 (60.8\%) women had vaginal delivery, and 156 (39.2\%) were women had the Caesarean section performed. 233 women (58.54\%) were primiparas, while 165 women (41.46\%) were multiparas

The full group characteristics are presented in Table 1.

\section{Female Sexual Function Index (FSFI) before and after pregnancy}

Pregnancy and childbirth significantly $(p<0.001)$ reduce female sexual activity by lowering FSFI score. A similar relationship occurs in the six domains included in the FSFI scale.

Detailed results are presented in Table 2.

The number of women who received $\leq 26$ points (which may indicate sexual dysfunctions) before pregnancy is $34(8.54 \%)$ and after giving birth it is 167 (41.96\%). Indeed $(p<0.001)$ the number of women with sexual dysfunction in the group of postpartum women increased. The result is shown in Figure 1.

Education, type of relationship, type of birth (vaginal delivery/caesarean section delivery), number of pregnancies, type of feeding does not affect the total score of FSFI and individual domains ( $p>0.05$ ). 


\begin{tabular}{|c|c|c|}
\hline Characteristics & No & (\%) \\
\hline \multicolumn{3}{|l|}{ Marital status } \\
\hline Marriage & 304 & $76.38 \%$ \\
\hline Informal partner & 94 & $23.62 \%$ \\
\hline \multicolumn{3}{|l|}{ Education } \\
\hline Higher education & 247 & $62.06 \%$ \\
\hline Secondary education & 113 & $28.39 \%$ \\
\hline Vocational education & 25 & $6.28 \%$ \\
\hline Basic education & 13 & $3.27 \%$ \\
\hline \multicolumn{3}{|l|}{ Place of residence } \\
\hline Village & 103 & $25.88 \%$ \\
\hline City $>250$ k inhabitants & 98 & $24.62 \%$ \\
\hline City $50-250$ k inhabitants & 134 & $33.67 \%$ \\
\hline City $<50$ k inhabitants & 63 & $15.83 \%$ \\
\hline \multicolumn{3}{|l|}{ Childbirth method } \\
\hline Vaginal delivery & 242 & $60.80 \%$ \\
\hline Caesarean section delivery & 156 & $39.20 \%$ \\
\hline $\begin{array}{l}\text { Complications during vaginal } \\
\text { delivery }\end{array}$ & 175 & $72.31 \%$ \\
\hline Epistotomy & 105 & $60 \%$ \\
\hline Perineal trauma & 41 & $23.43 \%$ \\
\hline $\begin{array}{l}\text { Epistotomy and perineal } \\
\text { trauma }\end{array}$ & 19 & $10.86 \%$ \\
\hline Vacuum/forceps delivery & 10 & $57.14 \%$ \\
\hline
\end{tabular}

The exact results gained from the patients about their satisfaction with sexual life before pregnancy and after childbirth is presented in Table 3.

\section{Vaginal delivery or Caesarean section delivery}

The occurrence of complications during childbirth of the vaginal birth causes a decrease in the total score and in each of the domains. The significant difference is statistically present in the total FSFI score $(p<0.01)$ and in the domains: desire $(p<0.01)$, excitement $(p<0.05)$, orgasm $(p<0.05)$, satisfaction $(p<0.01)$. Does not affect domains: Iubrication, pain $(p>0.05)$.

\section{Time of sexual initiation}

Almost one-third $(n=118)$ of patients began sexual initiation before the gynecological examination, recommended six weeks after delivery. It has been checked whether the time of initiation of sexual initiation after childbirth affects the FSFI score. Statistically significant difference appeared only in the domain of "pain" - in the group of women who were waiting six weeks after the birth with sexual initiation the result in this domain was $4.37 \pm 1.40$, while in the group of women who earlier than six weeks after the

\begin{tabular}{|l|l|l|l|}
\multicolumn{5}{|l}{ Table 2. Female Sexual Function Index score } \\
\hline Domain & Before pregnancy & After delivery & p \\
\hline Desire & $4.74 \pm 0.93$ & $3.69 \pm 1.37$ & $<0.001$ \\
\hline Arousal & $5.14 \pm 0.78$ & $4.39 \pm 1.33$ & $<0.001$ \\
\hline Lubrication & $5.46 \pm 0.78$ & $4.76 \pm 1.23$ & $<0.001$ \\
\hline Orgasm & $4.93 \pm 1.08$ & $4.54 \pm 1.30$ & $<0.001$ \\
\hline Satisfaction & $5.20 \pm 0.86$ & $4.61 \pm 1.22$ & $<0.001$ \\
\hline Pain & $5.09 \pm 1.04$ & $4.46 \pm 1.38$ & $<0.001$ \\
\hline FSFI score & $30.57 \pm 3.17$ & $26.46 \pm 6.20$ & $<0.001$ \\
\hline
\end{tabular}

FSFI - Female Sexual Function Index

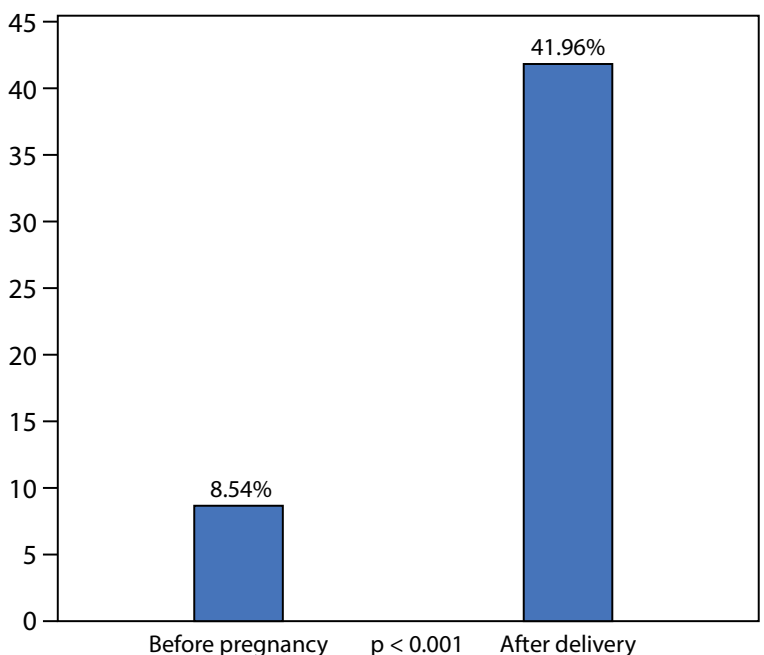

Figure 1. A significant increase in the number of patients with sexual dysfunction after delivery

Table 3. Assessment of satisfaction with sexual life

\begin{tabular}{l|l|}
\hline $\begin{array}{l}\text { How do you assess your } \\
\text { satisfaction with sexual } \\
\text { life before becoming } \\
\text { pregnant? }\end{array}$ & $\begin{array}{l}\text { How do you assess your satisfaction } \\
\text { with sexual life after childbirth? }\end{array}$ \\
\hline $\begin{array}{l}\text { Very good: } 247(62.06 \%) \\
\text { Good: } 117(29.40 \%)\end{array}$ & $\begin{array}{l}\text { Very good: } 91(22.86 \%) \\
\text { Good: } 115(28.89 \%)\end{array}$ \\
$\begin{array}{ll}\text { Rather bad: } 28(1.04 \%) & \text { Average: } 127(31,91 \%) \\
\text { Bad: } 2(0.50 \%) & \text { Rather bad: } 38(9.55 \%)\end{array}$ \\
\hline
\end{tabular}

birth began sexual initiation, the result in this domain was $4.68 \pm 1.34(p<0.05)$.

\section{Breastfeeding or modified milk}

The type of child's feeding by the surveyed patients is presented in Figure 2. More than half of our patients declare to be breastfeeding $(n=201)$, while $33.42 \%$ feed their babies with modified milk $(n=133) .12 .31 \%$ of the respondents mixed both techniques $(n=49)$, while $3.77 \%$ choose to bottle feed their babies with only pumped breastmilk. 15.33\% of women declare to feel less attractive to their partner 


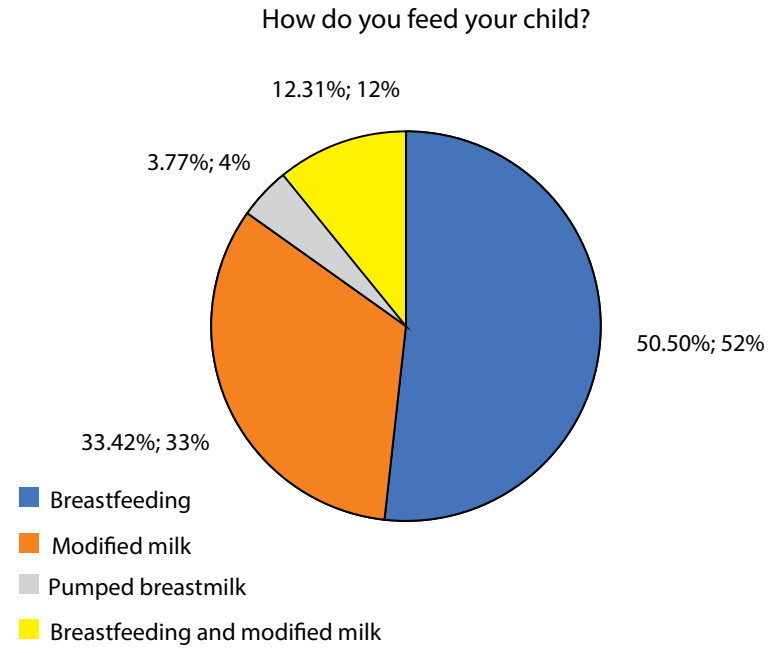

Figure 2. The type of child's feeding by the surveyed patients

through breastfeeding, however the type of baby feeding does not affect the FSFI score $(p>0.05)$.

\section{Tiredness}

Women were also asked how often they feel tired from the moment they gave birth. The answers were as follows: $42.96 \%(n=171)$ answered that the feeling of fatigue was very common, whereas $41.96 \%(n=167)$ said it was common. Also, the mood changes since childbirth was very common for $28.64 \%$ of patients $(n=114)$ and common for $37.69 \%$ of them $(n=150)$.

More than $79 \%$ ( $n=316$ ) of women admitted that fatigue resulting from child-care affected sexual initiation with their partner.

\section{Initiator of sexual intercourse}

For the question of "who the most often initiates sexual contact after childbirth?" $8.54 \%(n=34)$ of patients indicated themselves, while $54.77 \%(n=218)$ indicated their partners and $36.68 \%(n=146)$ said both.

Statistically significant differences were found as a result of FSFI depending on which partner initiates sexual intercourse. The result of FSFI when it is initiated by a woman or both partners is significantly higher than in the case when the partner initiate sexual intercourse. The exact parameters are presented in Figure 3.

\section{DISCUSSION}

The puerperium is defined in the literature as a six-week period after childbirth during which the pregnancy and childbirth changes withdraw and labor wounds heal. It is also connected with the initiation and maintenance of lactation and the re-initiation of ovarian function. During the puerperium, sexual intercourse is strictly forbidden [8, 9].

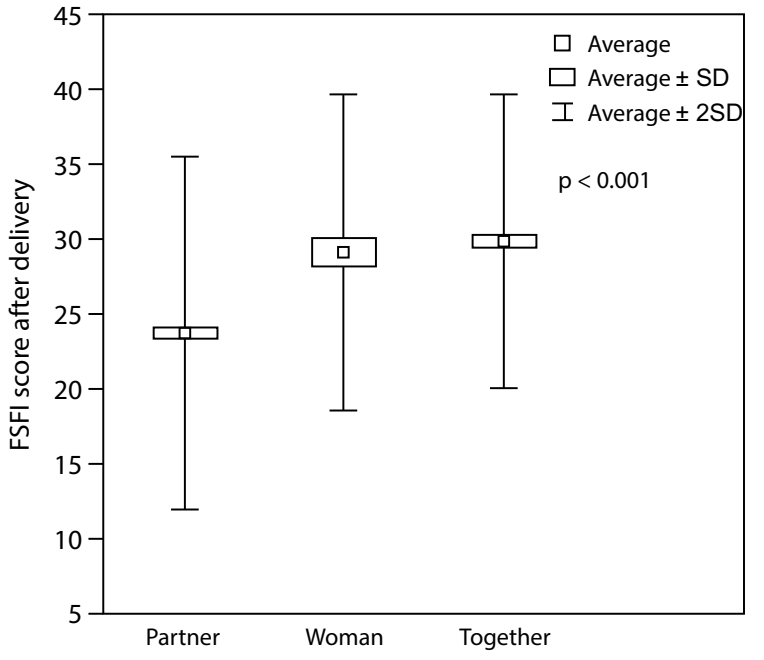

Figure 3. Female Sexual Function Index depending on sex initiator; FSFI — Female Sexual Function Index

Pregnancy process, delivery, postpartum and breastfeeding periods all affect physiological and mental functions that hinder women sexuality.

In the puerperium, women usually do not feel sexual needs. The first relation after giving birth raises fears and anxieties. They are usually associated with fear of pain, fear of becoming pregnant again or fear of damage to the stitched crotch [10,11].

More physical problems affecting women in the first year of maternity may include diminished vaginal lubrication, pain and discomfort upon intercourse, decreased sense of arousal and difficulty in achieving orgasm. All these symptoms are components of the Female sexual dysfunction (FSD) [12].

Female sexual dysfunction can be subdivided into desire, arousal, orgasmic and sexual pain disorders. Sexual pain disorders include dyspareunia and vaginismus [13].

\section{Desire}

In the postpartum period, it is common to find the problem in marital relations and a decrease in desire between partners is noticeable.

In the puerperium, women usually do not feel sexual needs. Motherhood brings close contact between mother and child through, for example, frequent breastfeeding. This usually satisfies the mother's need for intimacy. The first approach between partners usually takes place up to 12 weeks after delivery [14].

Lactation has a significant impact on sexual intercourse after delivery. Many women have reduced sexual excitability, weakness and slowed sexual reactions or decreased libido. The inhibition of libido during breastfeeding is influenced by hormones responsible for lactation [9, 14-16].

The time of lactation may be compared to the period of old age. At this time, insufficient congestion of female 
genitalia, sparse cervical mucus secretion, high vaginal sensitivity resulting from thin vaginal epithelium are observed. Women show less interest in sex and even indicate they do not want to have sexual intercourse. The reasons are tiredness, breast hypersensitivity and conflicts between partners $[14,16,17]$.

It is also important not to only feel desire but also feel desirable. However, it is often impossible without self-acceptance. From the studies carried out so far, it can be concluded that there are statistical differences between the sense of attractiveness of women before, during and after pregnancy and breastfeeding $[18,19]$.

It has been proven that during pregnancy the future mother's level of satisfaction increases. It is often connected to the breast enlargement. Body parts such as: hips, abdomen, buttocks, thighs, the appearance of the silhouette, legs or intimate organs are assessed worse than during the preconception period.

Indeed, the assessment of attractiveness is influenced also by the labor and the breast-feeding period. Women showed lower self-esteem concerning selected parts of the body such as: breasts, stomach, hips, buttocks, thighs, silhouette or intimate organs compared to the period before pregnancy. Notwithstanding, a lot of women feel even more attractive in this period due to being more aware of their body [19].

Lack of desire for women's sexual intercourse may also result from maternity blues. It is stated that almost $40 \%$ of women suffer from maternity blues, which generally involves symptoms such as: mood lability, tearfulness, mild anxiety and depressive symptoms [20, 21].

However, in $19 \%$ of cases, it may evolve into postpartum depression. The disease manifests as sleep disorders, mood swings, changes in appetite, fear of injury, serious concerns about the baby, much sadness and crying, sense of doubt, difficulty in concentrating, lack of interest in daily activities, thoughts of death and suicide. In this extreme case, the sexual life of women is very strongly disturbed, if it exists at all [22].

\section{Arousal and orgasmic}

During the first few months of maternity, decreased estrogen levels and elevated prolactin levels are observed. These changes, however, do not remain indifferent to the woman's sexual life. Such variations may lead to important sexual problems including vaginal dryness/insufficient lubrication. Women with this problem often suffer from vaginal irritation after intercourse, painful penetration, pain during sexual intercourse resulting in loss of sexual desire, lack of sexual satisfaction, tiredness and bruises/tear while that of non-resumption of coitus included unavailability of the husband [23].
The method of delivery also affects sexual life. Natural childbirth initially causes stretching of the muscles and, consequently, permanent relaxation of the muscles and fascia of the pelvic floor. The looser vagina, which is a consequence of passing the fetal head through the birth canal, has an adverse effect on achieving orgasm. Vaginal pelvic muscles exercises are recommended for vaginal changes caused by childbirth [9, 14, 24, 25].

An additional point that should be addressed is the role of the male partner that has many emotional, psychological, behavioral and interpersonal issues as a new father. The relationship factors had substantial impact on female sexual function in desire, arousal, orgasm and satisfaction where women's lubrication problems and sexual pain are related predominantly with biological factors [26].

\section{Sexual pain}

Natural delivery is not only reported leading to looser the vagina, but also to causing numbers of injuries. Only about $10 \%$ of women having a first baby will achieve a vaginal birth with no attendant perineal trauma [27].

Both, spontaneous injuries and the incision of the crotch performed during the labour affects sexual intercourse. Scientific research on the issue of episiotomy has proven its negative impact on the satisfaction with sexual life. In women who engage in sexual activity and who have had an episiotomy performed during childbirth, dyspareunia and secondary vaginismus is more commonly diagnosed [11, 14, 28-30].

Correct suturing of the crotch with attention to detail about anatomy and functionality allows the patient to enjoy better post-pregnancy sexuality [30].

The method of the delivery also seems to play important role in woman's frame of mind. It was confirmed that caesarean sections may reduce the prevalence of urinary incontinence. Also, having vaginal delivery and more than one child group of women has worse sexual function than caesarean delivery and single children group.

One cannot forget that the decreased libido in women in puerperium is usually associated with delivery complications. One of the most common may be postpartum urinary incontinence. Overall, its prevalence seems to be around $30 \%$ within the first three months. It can be a key factor causing the woman's reluctance towards sexual intercourse, which greatly decreases self-confidence [31].

\section{CONCLUSIONS}

Pregnancy and childbirth significantly reduce female sexual activity by lowering FSFI score. The number of women with sexual dysfunctions increases fivefold after giving birth and may even reach the value of $40 \%$ of young mothers.

Childbirth results in lack of libido and sexual satisfaction, tiredness and bruises, dyspareunia and impaired self-ac- 
ceptance in order to maintain women sexual health. It is important to prepare young parents for the changes taking place in the body as well as the psyche of the mother after childbirth as well as preparing them for the constant fatigue and changing of the priorities.

Notwithstanding, the role of the medical personnel in maintaining women's sexual health is extremely important. Medics need to ensure the most comfortable course for the pregnancy and delivery, with minimal trauma to the intimate area. Also, try as much as possible to prevent urinary incontinence and to teach patients how to deal with body adversities, such as reduced vaginal arousal, hormones fluctuations or pain.

\section{REFERENCES}

1. Phillips NA. Female sexual dysfunction: evaluation and treatment. American Family Physician. 2000; 62(1): 127-48.

2. Majda A, Zalewska-Puchała J, Kamińska A, et al. Uwarunkowania seksualności kobiet ciężarnych w Polsce. Hygeia Public Health. 2014; 49(4): 864-869.

3. Żak-Łykus A, Nawrat M. Satysfakcja seksualna, życiowa i partnerska. Sexual satisfaction, quality of life and relationship satisfaction. Family Forum. 2013; 3: 172-186.

4. World Health Organization (2010). Developing sexual health programmes: a framework for action. http://www.who.int/iris/handle/10665/70501.

5. Lewis RW, Fugl-Meyer KS, Corona G, et al. Epidemiology/risk factors of sexual dysfunction. J Sex Med. 2004; 1(1): 35-39, doi: 10.1111/j.1743-6 109.2004.10106.x, indexed in Pubmed: 16422981.

6. Zyśk N, Durka P. Wpływ macierzyństwa na seksualność kobiet. The impast of motherhood on women's sexuality. Polski Przegląd Nauk o Zdrowiu. 2015; 1(42).

7. Rosen R, Brown C, Heiman J, et al. The Female Sexual Function Index (FSFI): a multidimensional self-report instrument for the assessment of female sexual function. J Sex Marital Ther. 2000; 26(2): 191-208, doi: 10.1080/009262300278597, indexed in Pubmed: 10782451.

8. Smoliński R. Aktywność seksualna kobiet w ciąży. In: Lew-Starowicz Z, Skrzypulec V. ed. Podstawy seksuologii. Wydawnictwo Lekarskie PZWL, Warszawa 2010: 134-136.

9. Bręborowicz G. Połóg. In: Położnictwo i Ginekologia Tom 1, wyd 2. Wydawnictwo Lekarskie PZWL, Warszawa 2015.

10. Keskin D. Mode of Delivery and Number of Children Effect on Sexual Function. Middle Black Sea Journal of Health Science. 2018: 7-11, doi: 10.19127/mbsjohs.411483.

11. Matusiak-Kita M, Zdrojewicz Z. Seksulaność kobiet w ciąży, w okresie poporodowym i karmienia piersią. Przegląd Seksuologiczny. 2010; styczeń/marzec(21).

12. Allahdadi KJ, Tostes RCA, Webb RC. Female sexual dysfunction: therapeutic options and experimental challenges. Cardiovasc Hematol Agents Med Chem. 2009; 7(4): 260-269, doi: 10.2174/187152509789541882, indexed in Pubmed: 19538161.

13. American College of Obstetricians and Gynecologists. ACOG technical bulletin. Sexual dysfunction. No. 211., Washington, D.C. September 1995.

14. Sipiński A, Kazimierczak M, Ciesielska B. Ocena zachowań seksualnych kobiet karmiących. Seksuologia Polska. 2005; 3(2): 52-59.
15. Tenfelde S, Tell D, Brincat C, et al. Musculoskeletal Pelvic Pain and Sexual Function in the First Year After Childbirth. J Obstet Gynecol Neonatal Nurs. 2019; 48(1): 59-68, doi: 10.1016/j.jogn.2018.10.004, indexed in Pubmed: 30503526.

16. Sobel L, O'Rourke-Suchoff D, Holland E, et al. Pregnancy and Childbirth After Sexual Trauma: Patient Perspectives and Care Preferences. Obstet Gynecol.2018; 132(6): 1461-1468, doi: 10.1097/AOG.0000000000002956, indexed in Pubmed: 30399100.

17. Banaei M, Torkzahrani S, Ozgoli G, et al. Addressing the Sexual Function of Women During First Six Month After Delivery: Aquasi-Experimental Study. Mater Sociomed. 2018; 30(2): 136-140, doi: 10.5455/msm.2018.30.136-140, indexed in Pubmed: 30061806.

18. Martínez-Galiano JM, Hernández-Martínez A, Rodríguez-Almagro J, et al. Women's Quality of Life at 6 Weeks Postpartum: Influence of the Discomfort Present in the Puerperium. Int J Environ Res Public Health. 2019; 16(2), doi: 10.3390/ijerph16020253, indexed in Pubmed: 30658406

19. Machaj A, Stankowska I. Poczucie atrakcyjności seksualnej kobiet w wieku prokreacyjnym po przebyciu ciąży i okresu karmienia. Nowiny Lekarskie. 2011; 80(5): 323-333.

20. Faisal-Cury A, Menezes PR, Tedesco JJ, et al. Maternity “blues": prevalence and risk factors. Span J Psychol. 2008; 11(2): 593-599, indexed in Pubmed: 18988444.

21. Gavin NI, Gaynes BN, Lohr KN, et al. Perinatal depression: a systematic review of prevalence and incidence. Obstet Gynecol. 2005; 106(5 Pt 1): 1071-1083, doi: 10.1097/01.AOG.0000183597.31630.db, indexed in Pubmed: 16260528.

22. Ghaedrahmati M, Kazemi A, Kheirabadi G, et al. Postpartum depression risk factors: A narrative review. J Educ Health Promot. 2017; 6: 60, doi: 10.4103/jehp.jehp_9_16, indexed in Pubmed: 28852652.

23. Anzaku As, Mikah S. Postpartum resumption of sexual activity, sexual morbidity and use of modern contraceptives among nigerian women in jos. Ann Med Health Sci Res. 2014; 4(2): 210-216, doi: 10.4103/21419248.129044, indexed in Pubmed: 24761240.

24. Stadnicka G, Łepecka-Klusek C, Pilewska-Kozak A, et al. Satysfakcja seksualna kobiet po porodzie — część I. Problemy Pielęgniarstwa. 2016; 23(3): 357-361, doi: 10.5603/pp.2015.0058.

25. Golmakani N, Zare Z, Khadem N, et al. The effect of pelvic floor muscle exercises program on sexual self-efficacy in primiparous women after delivery. Iran J Nurs Midwifery Res. 2015; 20(3): 347-353, indexed in Pubmed: 26120335.

26. Eid MA, Sayed A, Abdel-Rehim R, et al. Impact of the mode of delivery on female sexual function after childbirth. Int J Impot Res. 2015; 27(3): 118-120, doi: 10.1038/ijir.2015.2, indexed in Pubmed: 25672800.

27. Thom DH, Rortveit $\mathrm{G}$. Prevalence of postpartum urinary incontinence: a systematic review. Acta Obstet Gynecol Scand. 2010; 89(12): 1511-1522, doi: 10.3109/00016349.2010.526188, indexed in Pubmed: 21050146.

28. Rogers RG, Borders N, Leeman LM, et al. Does spontaneous genital tract trauma impact postpartum sexual function? J Midwifery Womens Health. 2009; 54(2): 98-103, doi: 10.1016/j.jmwh.2008.09.001, indexed in Pubmed: 19249654.

29. Stadnicka G, Łepecka-Klusek C, Pilewska-Kozak A, et al. Satysfakcja seksualna kobiet po porodzie - część II. Problemy Pielęgniarstwa. 2015; 23(3): 362-366.

30. Filipek K, Marcyniak EM, Kuran-Ohde J. Jakość współżycia płciowego kobiet 6 miesięcy po porodach drogami natury a samoocena stanu sromu i krocza. Seksuologia Polska. 2014; 12(2): 58-63.

31. Thom DH, Rortveit G. Prevalence of postpartum urinary incontinence: a systematic review. Acta Obstet Gynecol Scand. 2010; 89(12): 1511-1522, doi: 10.3109/00016349.2010.526188, indexed in Pubmed: 21050146. 